\title{
ASSESSMENT OF THE PRODUCTIVITY OF LIVESTOCK IN AND OUTSIDE THE WASE GRAZING RESERVE
}

\author{
BUTSWAT, I.S., MBAP, S.T. and VIBIS, G.G. \\ Animal Production Programme, Abubakar Tafawa Balewa University, P.M.B. 0248, Bauchi, \\ Nigeria.
}

Received 09 February 1996, Accepted August, 1997

\begin{abstract}
The performance of livestock in Wase was assessed using flocks and herds in and outside the Wase Grazing Reserve. Age at first calving of cattle in and outside the grazing reserve was 5 years. The corresponding calving interval was 2 years. The calving percentage of 92 for cattle in the grazing reserve was higher $(P<0.05)$ than that of 54 for cattle outside the grazing reserve. Ages at first lambing of sheep in and outside were 12.5 and 13 months respectively. Lambing interval however, was 8.6 months while corresponding lambing percentages were 75 and 71 . Average age at first kidding in goats in the grazing reserve was 12 months while outside was 12.5 month. The kidding interval was 8 months while kidding percentage on the other hand was 56 in the reserve and 46 outside the reserve. The average lactation yieid of cows $(P>0.05)$ in the grazing reserve was 401.5 litres while outside was 486.0 litres. The mean growth rates of calves between 6 and 12 months in and outside the grazing reserve were 9.8 and $5.6 \mathrm{~kg} / \mathrm{month}$ respectively. The mean growth rates of lambs in and outside the grazing reserve were on the other hand 1.9 and 1.7 $\mathrm{kg} / \mathrm{month}$ respectively, while the corresponding kids growth rates were 1.6 and $1.3 \mathrm{~kg} /$ month. Mortality rates recorded in adult cattle, lamb and kids in the grazing reserve were $4.8 \%, 7$ and $7 \%$ while the rates outside the reserve were respectively $2.4,5$ and $18 \%$.
\end{abstract}

Keywords: Livestock, productivity, grazing reserve.

\section{INTRODUCTION}

The recurring feed crisis in African has led to renewed interest by African Governments and World Communities, to increase energy and protein supplies to Africa on a permanent basis (Nuru, 1988).

The role of livestock in providing protein is increasingly being recognised. What is also becoming evident is the catalytic function of livestock in increasing total farm output (Gryseels et al., 1984). It has been emphasised that during the fifth plan period, the livestock subsector would have to provide for increase in crude protein intake per adult from 15 grammes in 1985 to 35 grammes in 1990 (Suleinan, 1988). In Nigeria, out of the total meat supply from the domestic source, cattle account for $45 \%$, sheep and goats $35 \%$ and $20 \%$ from pigs and poulty (Nuru, 1978). About $95 \%$ of cattle in Nigeria are owned by the Nomadic Fulani herdsmen. These animals depend on natural grazing for their nutritional needs. This husbandry system however, does not conform with present reality.

Effort has been made by various governments in Nigeria to improve meat supply by cross-breeding local breeds of animals with imported breeds. This practice however, has been found to be expensive while the imported breeds and their crosses hardly get adapted to the local conditions. It was therefore, decided that improvement efforts should centre on improving the traditional herdman's condition (Alhassan and Shehu, 1988). The Federal Ministry of Agriculture in Nigeria through the National Livestock Development Project, United Nations Development Project and the Food and Agriculture Organisation decided to establish pilot grazing reserves in October, 1985 (Samviri and Santhirase-garam, 1985. The main reasons for establising the Grazing Reserves were to: evolve a better production system for traditional herdsmen, address the problem of dwindling land reserves due to 


\section{BUTSWAT ET AL}

other uses such as roads and civil construction. large-scale mechanized farming and expaning due to populition, redress the problem of inaccessibility of traditional grazing lands due to change of ownership, curtail conflict between traditional herdsmen and farmers due to trespasses.

Wase Grazing Reserve in Wase Local Government Area of Plateau State is one of those grazing reserves in which the research project was carried out. Other grazing reserves established include: Wawa-Zango and Jama'a in Bauchi State, Zamfara in Kebbi State, Kukar Jangorai in Borno State and Ubodu in Rivers State.

The objective of this study was to compare the productivity of livestock in the resarve with those outside the reserve and to provide baseline data that will be used for the planning and implementation of future settlement schemes.

\section{MATERIALS AND METHODS}

The study was carried out in two parts: April to July, 1994 and December, 1994 to February, 1995 to represent the wet and dry season in Wase respectively. The study involved livestock in and outside the Wase Grazing Reserve. Those outside were within $5 \mathrm{~km}$ radius of the reserve.

\section{Topography, Climate and Vegetation}

The Wase Grazing Reserve is located in Wase Local Government Area of Plateau State of Nigeria, between latitudes $9^{\circ} .05^{\prime}$ and $9^{\circ} .31^{\prime}$ North, longitudes $9^{\circ} .59^{\prime}$ and 10.35 East. Wase has an average rainfall of $777-811 \mathrm{~mm}$. The rainy season extends from March or April to September or October. Peak rainfall occurs between July and August and the lowest rainfall is between March and April. The average relative humidity at noon is $50-60 \%$. The hottest month is April $\left(29^{\circ} \mathrm{C}\right)$ at the onset of rains while the coldest period is from December to February $\left(25^{\circ} \mathrm{C}\right)$, the harmattan period. In Wase, ferrogenous soils are common soils and are generally of high fertility. The vegetation is an open savannah woodland with trees measuring up to 3 metres high or more. The commonest trees found in and around the grazing reserve included: Pankia clappertonia (locust bean tree); Ceiba pentandra (silk cotton tree); Andansonia digitata (baobab tree) while the common shrubs included: Acacia albida, Pterocapus erinaecious and Afzelia africana.

Thèse trees usually occured singly and, in some cases, in clusters while spaces in-between were occupied by a layer of non- woody herbs and grasses. The commonest herbs found in and around the reserve included: Amaranthus spinosus, A. hispidium, Acanthespenum hispidium while grasses commonly found are: Pennisetum pedicellatum, Pennisetum pupureum and Andropogon gayanus.

During the dry season, the grasses were generally brown with low nutritive value but at the onset of rainy season, there is succulent pasture with high nutritive value (Butswat and Mbap, 1993).

\section{Animals and their Management}

The breeds of cattle mostly found in Wase were the White Fulani, Sokoto Gudali and the Red Bororo, while sheep were predominantly the Yankasa and goats were mostly the Red Sokoto. The type of livestock management adopted by grazers in the grazing reserve was semi-intensive. Animals were allowed to graze freely in the day and brought back to the kraal at nights. Outside the grazing reserve, however, only cattle and sheep were allowed free grazing in the day time and brought back to the kraal at nights. Goats were tethered or kept in-doors and fed on grass during cropping season while in the dry season, they were allowed to roam freely.

In grazing reserve, animals were not housed whereas outside the grazing reserve, goats were housed in mud huts thatched with grass.

Animals (both in and outside the reserve) were not sprayed against ectoparasites. Ticks were picked manually and in some cases, kerosine was used to kill ecto-parasites. Animals were occasionally drenched. They were also vaccinated against rinderpest, contagious pleuro-pneumonia, black quarter, and anthrax. Animals were identificated by 
LIVESTOCK PRODUCTIVTY IN AND names, eartags, and where this was not possible, identification was through parentage, colour, body shape and size.

Only cows were milked and milking was usually done once a day in the morning.

\section{Dath Collection}

Visits were made monthly, questionnaires and measurements were used in data collection on age at first parturition, parturition interval, parturition rate and lactation length. The weights of cattle were measured by the use of weighbands, while sheep and goats were weighed using bathroom scales. Animals were weighed during each visit within the study period.

Calves were allowed to suckle their dams for 1-2 minutes before being milked. During each visit, livestock owners were persuaded to measure milk produced as accurately as possible. However, between visits the recorder relied on the information provided by the livestock owners. During each visit, new births, death, disease conditions and offtakes were noted.

\section{Data Analysis}

Chi-square test was carried out on herd size, herd structure, flock size and flock structure whereas analysis of variance was carried out on milk yield data.

\section{RESULTS}

\section{Animal Census}

Animal census conducted in 1994 in the wet season showed 2000 cattle, 500 sheep and 220 goats in the grazing reserve; 709 cattle, 250 sheep and 240 goats outside the grazing reserve. In the dry season on the other hand, the numbers had gone down reasonably (Table 1).

\section{Cattle Herd Size, Structure and Reproductive Performance}

Average herd sizes of cattle in and outside the grazing reserve were 66 and 24 respectively (Table 2). These herd sizes were significantly different $(P<0.05)$. Table 3 shows the herd structure for cattle indicates that heifers were more in and outside the grazing reserve. Chi-square contingency test showed significant
OUTSIDE GRAZING RESERVES difference $(P<0.05)$ between herd structures.

Age at first calving for cattle in and outside the grazing reserve was 5 years while calving interval was 2 years. Calving percentages however, were 92 and 54 respectively. Chi-square test carried out on difference between calving percentages showed significant difference $(\mathrm{P}<0.05)$. More births were recorded at the beginning of rains, May/June (Figure 1) than in other months.

\section{Growth Rate, Lactation Performance, Disease and Mortality}

The mean growth rates of calves in and outside the grazing reserve were 9.8 and 5.6 $\mathrm{kg} /$ month respectively. These mean growth rates were different $(t=8.07, P<0.05)$. It was observed (Figure 2) that season had significant effect on the growth of calves. Growtin started slowly but the rate increased until a maximum was reached at weaning age of 1 year.

Table 4 shows the milk productivity of cows understudied. There was no significant difference between two herds. Similarly, t-test $(t=1.12)$ did not indicate any significant difference between them.

The most predominant diseases recorded in and outside the grazing reserve were Trypanosomiasis, Fascioliasis, Contagious bovine Pleuro Pneumonia and babesiosis. The mortality rates recorded in adult cattle in and outside the grazing reserve were $4.8 \%$ and $2.4 \%$ respectively, but these did not differ significantly $(P>0.05)$. There was however no mortality in calves and young cows.

\section{Sheep}

Flock size, structure

Table 5 shows the average flock sizes in and outside the grazing reserve. There were more sheep in than outside the reserve. The flock sizes however, were not significantly different. The flock structures of sheep in and outside the grazing reserve are presented in Table 6 . The average percentages shows that the reserve had more adult ewes and lambs within than outside the reserve.

The difference between average percentage 
TABLE 1: ANIMAL CENSUS IN AND OUTSIDE THE GRAZING RESERVE.

\begin{tabular}{lllll}
\hline Season & Location & Cattle & Sheep & Goats \\
Dry season & (in Reserve) & 1,110 & 76 & 150 \\
& (outside Reserve) & 659 & 150 & 140 \\
Wet season & & & & \\
& (In Reserve) & 2,000 & 500 & 220 \\
& (outside Reserve) & 709 & 250 & 240 \\
\hline
\end{tabular}

TABle 2: HERD SIZES IN AND OUTSIDE THE GRAZING RESERVE.

\begin{tabular}{lcc} 
Number of herds & Grazing reserve & Outside grazing reserve \\
Number of animals & 8 & 7 \\
Average herd size & 535 & 170 \\
Chi-square value $=19.6^{*}$ & 66 & 24 \\
\hline
\end{tabular}

*Significant at $5 \%$

TABLE 3: HERD STRUCTURE IN AND OUTSIDE THE GRAZING RESERVE.

Calves under one year

Heifers 1 to 3 years

Bull calves 1 to 3 years

Breeding cows

Bulls

Castrates

Chi-square contingency value $=39.18^{*}$

\section{Grazing reserve (\%)}

23

38

4

22

(i)

4
Outside grazing reserve (\%)

\section{7}

24

5

I8

20)

5

*Significant at $5 \%$

flock structure was significant $(P<0.05)$.

\section{Reproductive performance, Growth rate, Diseases and Mortality}

The age at first lambing of sheep in the grazing reserve was 12.5 month while the age of sheep at first lambing outside the grazing reserve was 13 months. Chi-square test did not show any significant different between the ages at first lambing. Similarly, lambing interval was 8.6 months both in and outside the grazing reserve.

The lambing percentages were 75 and 71 in and outside the grazing reserve respectively. Chi-square test carried out on difference between lambing percentages did not show significant difference.

Figure 4 shows the lambing distribution in sheep in and outside the grazing reserve. Higher births were recorded both in and outside the grazing reserve in June/July than in any other months, while least births were recorded in the months of January, February,
November and December. The figure also showed two-twin births in the months of June and August.

Figure 5 shows the growth rates of lambs. The mean growth rates of animals $(P>0.05)$ in and outside the grazing reserve were 1.9 and $1.7 \mathrm{~kg} /$ month respectively. In both cases, growth started slowly and thereafter the rate increased with age.

On the other hand, the effect of season on growth of adult sheep is represented in Figure 6. Scasonal differences were observed in the weight of adult sheep in and outside the grazing reserve. Weight increased from April to December and decreased from January to March.

The most predominant sheep diseases in and outside the grazing reserve were the contagious pleuropneumonia, diarrhoea and fascioliasis. Though diarrhoea and fascioliasis were most frequent, foot rot and mouth diseases were commonest during the rainy season. 
LIVESTOCK PRODUCTIVTTY IN AND OUTSIDE GRAZING RESERVES
TABLE 4: MILK YIELD OF COWS IN AND OUTSIDE THE GRAZING RESERVE.

\begin{tabular}{|c|c|c|c|c|}
\hline Location & Name of owner & Number of cows & $\begin{array}{l}\text { Average } \\
\text { Lactation } \\
\text { yield (litres) }\end{array}$ & $\begin{array}{l}\text { Average yield } \\
\text { per day (litres) }\end{array}$ \\
\hline \multirow[t]{4}{*}{ Grazing Reserve } & Mal. Garga & 37 & 408.8 & 1.12 \\
\hline & Alh. Ganija & 38 & 343.1 & 0.94 \\
\hline & Mal. Musa & 14 & 452.6 & 1.24 \\
\hline & \multicolumn{4}{|c|}{ F-test value $=3.106^{\mathrm{NS}}$} \\
\hline \multicolumn{5}{|c|}{ Outside Grazing reserve } \\
\hline & Lamtak & 16 & 438 & 1.2 \\
\hline & Moses & 23 & 584 & 1.6 \\
\hline & \multicolumn{4}{|c|}{ F-test value $=5.995^{\mathrm{NS}}$} \\
\hline
\end{tabular}

\section{TABLE 5: FLOCK SIZES OF SHEEP IN AND OUTSIDE THE GRAZING RESERVE.}

\begin{tabular}{llc}
\hline & Grazing reserve & Outside grazing reserve \\
\hline Number of flocks & 8 & 5 \\
Number of animals & 146 & 76 \\
Average flock size & 18 & 15 \\
Chi-square value $=0.28^{\text {NS }}$ & & \\
\hline
\end{tabular}

NS $=$ not significant.

TABLE 6: FLOCK STRUCTURES IN AND OUTSIDE THE GRAZING RESERVE.

\begin{tabular}{lcc}
\hline & Grazing reserve (\%) & Outside grazing reserve (\%) \\
\hline Lambs under 6 months & 23 & 10 \\
Lamb ewes between 6 and 10 months & 15 & 33 \\
Lamb rams between 6 and 10 months & 6 & 8 \\
Adult ewes & 38 & 10 \\
Adult rams & 4 & 4 \\
Chi-square contingency value $=13.40^{\circ}$ & & \\
\hline
\end{tabular}

* Significant at $5 \%$

TABLE 7: HERD SIZE IN AND OUTSIDE THE GRAZING RESERVE.

\begin{tabular}{lcc}
\hline & Grazing reserve (\%) & Outside grazing reserve (\%) \\
\hline Number of herds & 8 & 5 \\
Number of animals & 125 & 76 \\
Average herd size & 16 & 15 \\
Chi-square value $=0.032^{\mathrm{NS}}$ & & \\
\hline
\end{tabular}

$$
\text { NS }=\text { not significant. }
$$



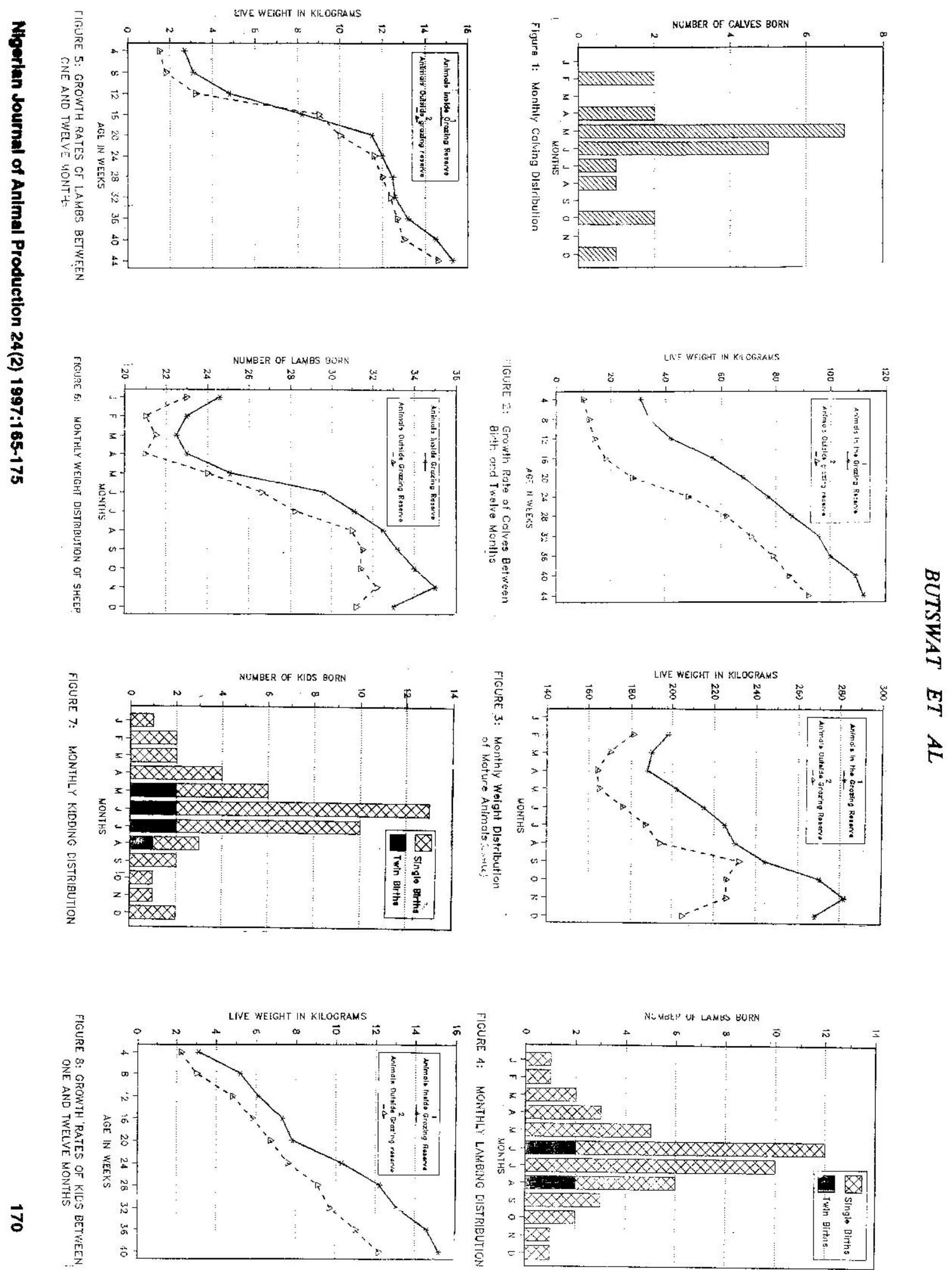


\section{LIVESTOCK PRODUCTIVTY IN AND OUTSIDE GRAZING RESERVES TABLE 8: HERD STRUCTURES OF GOATS IN AND OUTSIDE THE GRAZING RESERVE.}

Grazing reserve (\%)

Outside grazing reserve $(\%)$
Kids 6 months

Kid does between 6 and 10 months

Kid bucks between 6 and 10 months

Adult dóes

Chi-square contingency value $=3.378^{\mathrm{NS}}$

$\begin{array}{ll}34 & 33 \\ 15 & 16 \\ 12 & 4 \\ 39 & 47\end{array}$

NS = not significant.

Mortality rate of $7 \%$ was recorded in lambs in the grazing reserve. Outside the grazing reserve, however, mortality rate of $5 \%$ was recorded in adult sheep while no death was recorded in lambs. Differences between the mortality rates were not significant $(P>0.05)$

\section{Goats}

\section{Herd size and structure}

Table 8 shows the herd sizes of goats in and outside the grazing reserve. The average herd size outside $(P>0.05)$ was 15 goats while the average herd size in the grazing reserve was 16 goats. The herd percentages of goats in and outside the grazing reserve are presented in Table 8 .

\section{Reproductive performance, Growth rate, Disease and Mortality}

The age at first kidding of goats in the grazing reserve was 12 months, while outside, the age at first kidding was 12.5 months $(P>0.05)$. Kidding interval however, was 8 months both in and outside the reserve. Average kidding percentages $(P>0.05)$ were 56 and 46 for goats in and outside the grazing reserve respectively. Kidding distribution showed that highest births were recorded in June/July (Figure 7) both in and outside the grazing reserve. Lowest births were, however, recorded in the months of January, October and December. The figure also indicates more twin than single births with the highest twinning in June.Figure 8 shows the growth rates of young goats. The mean growth rates of kids $(P>0.05)$ in and outside the grazing reserve were $1.6 \mathrm{~kg}$ and $1.3 \mathrm{~kg} / \mathrm{month}$ respectively. In both cases growth started slowly but the rate increased until mature weights were reached at 10 months.

The effect of season on growth of mature goats is represented in Figure 9. The figure indicates that in the grazing reserve, weights of matured goats increased during the onset of rains (April) and decreased during peak rains (August/September) while outside the reserve, weights decreased at the onset of rainy season up to November.

The commonest diseases of goats in and outside the grazing reserve were the contagious caprine pleuropneumonia, diarrhoea, fascioliasis, foot rot and mouth disease. Foot rot, diarrhoea and fascioliasis were however, more frequent during the rainy season. The mortality rate of $18 \%$ was recorded in adult goats outside the grazing reserve. Inside the grazing reserve on the other hand, $7 \%$. mortality in adults. $(\mathbf{P}<0.05)$ rates was recorded in kids with no mortality.

\section{DISCUSSION}

\section{Herd/flock size, structure and Reproductive Performance}

The average herd sizes of 66 and 24 for cattle in and outside the grazing reserve (Table 2) are lower than the value of 72 reported by Raay (1975) in White Fulani in the savannah region of Nigeria and Pullan (1979) in White Fulani on the Jos Plateau. The higher cattle herd size in than outside the grazing reserve could be attributed partly to the fact that farmers outside the grazing reserve were more involved in crop farming and so kept fewer animals. The flock sizes of sheep in and outside the grazing reserve (Table 6) are lower than the values of 19 and 17 sheep reported by Wilson (1986) under rice 
and miller straw feeding in central Mail. The average herd sizes of goats in and outside the grazing reserve respectively (Table 8 ) on the other hand are in conformity with values reported in southern Nigeria, Danfur (Wilson, 1976).

The average cattle herd structure points to high number of heifers aged 1 to 3 years (Table 3) in and outside the grazing reserve. These results are in contrast to the reported value of $9 \%$ in herds on the Jos Plateau (Pullan, 1979) and 14\% in Central Mali (Wilosn, 1986). The reason for the higher number of heifers aged 1 to 3 years in this study could be due to the low mortality rate in calves. On the other hand, the values of 22 and $20 \%$ of breeding cows (Table 3 ) are lower than the values of 45 and $40 \%$ reported in herds on the Jos Plateau (Pullan, 1979) and Central Mali (Wilson 1986) respectively. The higher percentage bulls outside than in the grazing reserve could be because of the fewer breeding cows outside the grazing reserve with low calving rate. Farmers therefore keep more males to boost herd size since cattle size per se is used as a measure of wealth and not their productivity. In addition, more males were kept outside the reserve for draught purposes. The average kids percentages are higher than kids in pastoral and agro-pastoral managment respectively in Central Mali (Wilson, 1986).

The age at first calving of 5 years for cattle in and outside the grazing reserve is consistent with the reported values under traditional management system (Pullan, 1979; Otchere, 1986 and Nuru, 1988). This prolonged age at first calving however, could be attributed to seasonal nutritional stress (Pullan, 1979); Voh and Otchere, 1989); delayed age at first calving could also be due to the genotype of animals (Hetzel $e t$ al., 1990). The ages at first lambing of 12.5 and 13 months for sheep in and outside the grazing reserve are in conformity with the values reported by Adu (1975) and Wilson (1976). However, the values appear low when compared to those reported by Molokwu and Umunna (1980) Similarly, the ages at first kidding of goats in and outside the grazing reserve are lower than earlier reported values
(Adu and Ngere, 1979; Wilson, 1986; Mbap and Ngere, 1989). Calving interval vatue of 2 years reported in this study is lower than the value reported by Pullan (1979) and Otchere (1984) under traditional management system. However, this result agrees with calving interval reported on government farms and research stations (ILCA/DER, 1978). Mating heifers earlier in life has been observed to give considerably longer first calving intervals (Oyedipe et al., 1982).

Lambing interval of 8.6 months recorded in sheep in this study appears to be less than the reported value of 10.4 months (Molokwu and Umunna, 1980), but is consistent with the values reported by Dettmers et al. (1976) and Buvanendran and Adu (1987) in West African dwarf sheep and Balami respectively. Kidding interval of 12.5 months recorded in this study is higher than the values of 9.7 months and 10.6 months reported by Mbap and Ngere (1989) in West African Dwarf and Red Sokoto goats respectively. The long kidding interval could be due to prolonged postpartum ancestrous (Davendra and Burns, 1970). Calving percentage of 92 of cattle inside the grazing reserve appears high when compared to reported calving percentages of 54 and 55 by Nuru and Dennis (1976) and Voh et al. (1989) respectively. A high calving percentage in a herd may be attributed to high number of fertile breeding cows. Monthly calving distribution (Figure 1) showed that more births were recorded at the beginning of rains, May/June. The monthly calving distribution is consistent with earlier reports (Pullan, 1976; Voh and Otchere, 1989), and indicates that even in the absence of controlled mating in and outside the grazing reserve, mating is somewhat self regulating and this is attributed to the relationship between nutrition and fertility.

Lambing percentages recorded for sheep are lower than the lambing rate of $176 \%$ reported in Yankasa (Ferguson, 1964). This could be related to availability of feed and retention of old non-productive ewes. Monthly lambing distribution of sheep in May/June (Figure 4) indicate that conception 

occured in January/February when feed scarcity has not become a serious problem.

Average kidding percentages obtained here for goats are lower than the values of 180 and 175 reported in Red Sokoto and West African Dwarf goats (Nuru, 1985). The lower average kidding percentages outside the grazing reserve could be due to tethering of goats during the rainy season. Monthly kidding distribution of goats in and outside the grazing reserve on the other hand showed peak in the months of June/July (Figure 7). This indicates that peak conception occured in February/March. This result is in contrast with what has been reported in Southern Danfur (Wilson, 1976), where there were two peaks; first was recorded in May and the second was in September/October.

\section{Growth rate and Lactation Performance}

The growth rate of calves in the grazing reserve was faster than growth rate of calves outside the grazing reserve (Figure 2). The significant difference between the growth rates of calves in and outside the grazing reserve could be due to the obviously longer grazing time and higher pasture availability in than outside the grazing reserve since growth rates of animals are highly related to feed availability (Adu and Brinckman, 1981). In addition, the seasonal changes in the mature weights of cattle in and outside the grazing reserve (Figure 3) could also be due to seasonal variation in pasture availability. In the dry season, pasture fluctuation worsens the body condition of mature cattle since they have to trek long distances in search of food (Loosli and Van Blake, 1978). The increase in growth rate of lambs during the first 3-4 months of life (Fig. 5), could be attributed to the availability of dam's milk which is related to pasture availability. The seasonal weight changes of mature sheep in and outside the grazing reserve could also be as a result of seasonal availability of pasture in and outside the grazing reserve as has been observed for cattle. These weight changes are consistent with an earlier report by Wilson (1976) in which weights of mature sheep decreased during the dry season but increased at the beginning of rains. Same also applied to the growth rate of kids (Fig. 8).

The increase in mature weight of goats outside the grazing reserve during the dry season with a subsequent decrease during the rainy season could be due to tethering in the wet season which reduces feed availability. When they were let loose during the dry season however, they were able to scavenge for food freely, thus resulting in weight increases. The opposite result recorded for goats in the grazing reserve on the other hand could be due to higher pasture availability in the grazing reserve in the wet than dry season.

The average lactation yields conform with earlier reports on the milk yield of the Zebu cattle under traditional management system (de. Leeuw et al., 1982; Wilson, 1986). Lactation length of between 1 to 1.5 years in this stuty also agrees with the earier report by Butswa: and Mbap (1993).

\section{Disease and Mortality rates.}

The major diseases of livestock such as pleuropnemonia, babesiosis, anaplasmosis, brucellosis, fascioliasis, trypanosomiasis, foot and mouth diseases reported in this study are similar to earlier reports (Haruna, 1981 and Butswat and Mbap, 1993). The productivity of livestock could be enhanced by proper control of these diseases (Haruna, 1981).

The herd mortality rates recorded here for adult cattle are similar to adult cattle mortality rates of 4.8 and $3.8 \%$ reported by Wilson (1986) in central Mali. Very unusual however, no mortality was recorded in calves and young cows in this study. Calf mortality rate of $24 \%$ has been reported in White Fulani herds on the Jos Plateau (Pullan, 1980).

The mortality of $7 \%$ recorded in lambs in the grazing reserve in this study is lower than the $41.2 \%$ reported by Mukasa-Mugerwa and Tekelye (1988). On the other hand, the 5\% mortality rate recorded in adult sheep outside the grazing reserve is lower than the reported value of $46.4 \%$ (Wilson, 1986). Similarly, the adult goats mortality rate of $18 \%$ outside the grazing reserve is lower than the $38 \%$ mortality rate reported in adult in cental Mali (Wilson, 1986). Mbap and Ngere (1989), on the other hand, reported mortality rates of 


\section{BUTSWAT ET AL}

41.5 and $32.5 \%$ in Red Sokoto and West African dwarf goats respectively.

Therefore the overall performance of livestock obtained in this study in relation to levels obtained under improved management indicates that the indigenous livestock have potential performance far greater than the level achieved under traditional management system. Thus, substantial improvement can be achieved through better management. Pasture availability seems to be the most important factor in the productivity of the animals. Efforts should therefore be geared towards dry season supplementation to ensure that the productivity of livestock is not constrained by seasonal factors. By ensuring adequate and effective supplementation programme, the potentials of our indigenous breeds of livestock could be tapped thereby conserving the large sums of money that are being invested in importing exotic breeds which hardly adapt to our local conditions.

\section{REFERENCES}

ADU, I.F. (1975). The effect of steaming up on the birth weight, lactation and growth of West African Dwarf Sheep. Ph.D. Thesis, University of Ibadan, Nigeria.

ADU, I.F. (1978). A decade of small ruminant production. National Animal Production Research Institute. Annual Reports. 1977 - 1979.

ADU, I.F. and BRINCKMAN, W.L. (1981). Feedlot performance and carcass characteristics of sheep fed varying concentrate levels. Journ of Anim. Prod. Res. 1(1):1-8.

ADU, I.F. AND NGERE, L.O. (1976). The indigenous sheep of Nigeria. World Review of Animal Production, 15(3):51-56.

BUTSWAT, I.S. and MBAP, S.T. (1993). Assessment of productivity of livestock in Wase Grazing. Reserve, Plateau State, Nigeria. Proceedings of Intern. Workshop on Livestock Systems Research. Zaria, Nigeria. 12-16 July, 1993.

BUVANENDRAN, V. AND and I.F. (1987). Balami sheep performance in Nigeria. Journal of Animal Production.

BUVANENDRAN, V,, DIM, N.I. AND ONI, O.O. (1989). Factors affecting birth weight and performance to weaning of Bunaji calves. Journal of Agricultural Sclence (Cambridge), 111:407-140.

dE LEEUW, P.N. and KONANDREAS, P.A. (1982). The use of an integral and atochastic model to estimate the productivity of our agropastural production systems in West Africa. Proceedings of the National Conference on Beef Production, Kaduna. Nigeria. July 27-30, 1982.

DETTMERS, A.E., IGBOCHE, S.A. and KIKELOMO, A (1976). The West African Dwarf sheep I: Reproductive performance and growth in Nigeria. Journal of Animal Production, 3: 139-147.

DAVENDRA, C. and BURNS, M. (1970). Goat production in the tropics. Commonwealth Agricultural Bureau, Farnham Royal, England.

DIALLO, A.K, SAYERS, E.R. and WEGANAAR, K.T. (1986). Productivity of trashumant Fulani cattle to the inner Niger Delta of Mali. ILCA. Research Report (13),
Addis Ababa.
FERGUSON, W. (1964). The development of sheep and gost production in the northern region of Nigeria. First F.A.O. African Regional Meeting, Addis Ababa, 1963.

GRYSEELS, G., ABIYE, A., ANDERSON, F.A. AND GETACHEW, A (1984). The role of mixed farming in
agriculture. ILCA Bulletin, 18: 20-23

HARUNA, M.W.D. (1981). A study of Bovine Mastitis on dairy herd. H.N.D. Discertation in Animal Health and Husbandry, College of Agriculture and Animal Science, Mando, Kaduna, Nigeria.

HETZEL, D.J.S, MACKINNON, M.J. and TAYLOR, J.F. (1990). Genetic variation co-variation in beef cow and bull fertility. J. Anim. Scl., 68: 1208-1214.

ILCA/DER (1978). Evaluation of the productivity of the Maure and Peul breeds of cattle at the Station ou Sabel, Niono. ILCA Monograph (1), ILCA, Addis Ababa, Ethiopia.

LOOSLI, J.K. and VAN BLAKE, H. (1978). The tropical environment and animal productivity. Animal Production in the Tropics. Heineman Educational Books Ltd. Ibadan. pp. 1-11.

MBAP, S.T. and NGERE, L.O. (1989). Observation on reporduction and kids performance of goats in the humid tropics. Nig. Journ. of Agric. Tech., I: 69-80.

MOLOKWU, E.C.I. and N.N. UMUNNA (1980). Reproductive performance of the Yankasa sheep of Nigeria. Theriogenolgy, 4: 237-241.

MUKASA-MUGERWA, E. and TEKELYE, B. (1988). Diseases: Important causes of reproductive wastage in sheep. Reproductive Animal Science, 16 and 17(4): 95-99.

NURU, $S$. (1985), Trends in small ruminants production in Nigeria. In: Proceedings of National Conference on Small Ruminant Production in Nigeria 6-10 October, 1985, NAPRI, Zaria, Nigeria. Pp. 34-41.

NURU, S. (1988). Research and development in pastoral production system in Nigeria: Past, present and future. An invited paper presented at the National Conference on Pastoralism in Nigeria held from 26-29th June, 1988. NAPRI, A.B.U. Zaria, Nigeria.

NURU, S. and DENNIS, S.M. (1976). Abortion and reproductive performance of cattle in Northern Nigeria. A questionnaire survey. Tropical Animal Health and Produclion, 8: 213-219.

OTCHERE, E.C. (1984). Traditional cattle production in sub-humid zone. ILCA sub-humid zone programme. Proceedings of the second ILCANAPRI Symposium held in Kaduna, Nigeria. pp. 110-140. Livestock Centre for Africa, Addis Ababa, Ethiopia.

OTCHERE, E.C. (1986). Traditional cattle production in the sub-humid zone of Nigeria: Livestock systems research in Nigeria's sub-humid zone. Proceedings of second ILCANNAPRI Symposium, Kaduna, Nigeria, 1984. Livestock Centre for Africa, Addis Ababa,
Ethiopia.

OYEDIPE, E.O., BUVANENDRAN, V. and EDUVIE, L.O. (1982). "Some factors affecting the reproductive performance of White Fulani cattle. Tropical Agriculture (Trinidad), 59:231-234.

PULLAN, N.B. (1979). Productivity of White Fulani cattle on the Jos Plateau. III. Disease and management factors. Tropical Animal Health and Production, 12: 17-84.

RAAY, A.B. (1975). Annual Reports. Department of Agriculture, Northem Region, Nigeria. pp. 53-56.

SULEIMAN, A.H. (1988). Policy issues in pastora! development in Nigeria. Invited paper for conference on pastoralism in Nigeria. NAPRI, A.B.U., Zaria. June, 1988.

VOH, A.A. JR and OTCHERE, E.O. (1989). Reproductive performance of Zebu cattle under agropastoral management in Northern - Nigeria. Animal Reproduction Science, 19:191-210

WILSON, R.T. (1976). Studies on the livestock of southern Danfur, Sudan. IV. Production traits in goats. Tropical Animal Health and Production, 8:221-232

WILSON, R.T. (1986). Livestock in central Mali: Long term studies on cattle and small ruminants in the agropastoral system 